\title{
МІКРОСКОПІЧНІ ЗМІНИ НЕЙРОЦИТІВ КОРИ МОЗОЧКА В ДИНАМІЦІ ЗА УМОВ ЕКСПЕРИМЕНТАЛЬНОЇ ТЕРМІЧНОЇ ТРАВМИ
}

\section{Мікроскопічні зміни нейроцитів кори мозочка в динаміці за умов експериментальної термічної травми}

\section{Н. В. Огінська, 3. М. Небесна}

Тернопільський національний медичний університет імені І. Я. Горбачевського МОЗ України

Резюме. Термічна травма як стрес-чинник екзогенного походження, при якому відбувається розвиток поліорганної недостатності та порушення фуункціонування органів та систем організму. Нервова система одна із перших сприймає і дає відповідь на больові імпульси. Важливим є реорганізація усіх структурних компонентів мікроциркуляторного русла та нейроцитів у результаті ендогенної інтоксикації, яка розвивається при термічній травмі. Мішенню при ураженнях виступає мозочок як поліфункціональний орган чентральної нервової системи.

Мета дослідження - встановити мікроскопічну реорганізацію нейроцитів кори мозочка у динаміці за умов експериментальної термічної травми шкіри.

Матеріали і методи. Експериментальне дослідження виконано на 24 статевозрілих білих щурахсамцях масою 180-200 г. Моделювання опіку III cmyпеня здійснювали мідними пластинами, які нагріті у кип'яченій воді до температури 97-100 на епільовану поверхню шкіри тіла тварин під тіопентал-натрієвим наркозом. Розміри ділянок ураження склали 18-20\% тіла щурів. Забір матеріалу для мікроскопічного дослідження проводили відповідно до загальноприйнятих методик. Гістологічні зрізи, отримані на санному мікротомі товщиною 5-6 мкм, забарвлювали гематоксиліном та еозином, толуїдиновим синім за методом Ніссля. Напівтонкі зрізи, виготовлені на ультрамікротомі $L K B-3$, забарвлювали метиленовим синім. Мікропрепарати вивчали за допомогою світлового мікроскопа MICROmed SEO SCAN ma фротодокументували за допомогою відеокамери Vision CCD Camera з системою виводу зображення з гістологічних препаратів.

Результати. Мікроскопічні дослідження показали взаємозалежність між терміном експерименту та порушенннями у структурних компонентах нейроцитів усіх шарів кори мозочка. У ранні терміни досліду відбуваються реактивні зміни, які носять пристосувальнокомпенсаторний характер із початковими деструктивними ушкодженнями. На 14 добу, а особливо через 21 добу спостерігаються поліморорізм, значна дегене-
Microscopic changes in the neurocytes of the cerebellar cortex in dynamics under conditions of experimental thermal injury

N. V. Ohinska, Z. M. Nebesna

I. Horbachevsky Ternopil National Medical University e-mail: nebesna_zm@tdmu.edu.ua

Summary. Thermal injury as a stress factor of exogenous origin, in which the development of multiple organ failure and dysfunction of organs and systems of the body occur. The nervous system is one of the first to perceive and respond to pain impulses. It is important to reorganize all the structural components of the microcirculatory tract and neurons as a result of endogenous intoxication, which develops during thermal trauma. The target of lesions is the cerebellum, as a multifunctional organ of the central nervous system.

The aim of the study - to establish the microscopic reorganization of neurocytes of the cerebellar cortex in the dynamics under conditions of experimental thermal trauma to the skin.

Materials and Methods. The experimental study was performed on 24 adult white male rats weighing 180-200 g. Simulation of third-degree burns was performed with copper plates heated in boiled water to a temperature of 97-100 on the epilated surface of the skin of animal bodies under thiopental sodium. The size of the affected areas was 18-20\% of the body of rats. Collection of material for microscopic examination was performed in accordance with generally accepted methods. Histological sections obtained on a sled microtome 5-6 $\mu \mathrm{m}$ thick were stained with hematoxylin and eosin, toluidine blue by the method of Nissl. Semi-thin sections made on an ultramicrotome $L K B-3$ were stained with methylene blue. The micropreparations were studied using a MICROmed SEO SCAN light microscope and photodocumented using a Vision CCD Camera with a histological image output system.

Results. Microscopic studies have shown an interdependence between the duration of the experiment and abnormalities in the structural components of neurons in all layers of the cerebellar cortex. In the early stages of the experiment there are reactive changes, which are adaptivecompensatory in nature with initial destructive damage. On day 14, and especially after 21 days, polymorphism is observed, significant cell degeneration, manifested by pycnosis of the nuclei, the development of intra- and pericellular edema in neurons of the granular, ganglionic and granular layers of the cerebellar cortex. 
рація клітин, що проявляється пікнозом ядер, виявляється розвиток інтра- та перицелюлярних набряків у нейронах зернистого, гангліонарного та зернистого шарів кори мозочка.

Висновки. Встановлено, що за умов експериментальної термічної травми відбувається реорганізація нейроцитів кори мозочка. На 1 i 7 добу досліду спостерігається зміна форми перикаріонів нейронів, гіперхромія ядер, внутрішньоклітинний набряк. У віддалені терміни відбувається наростання дестуруктивно-дегенеративних змін, що проявлялися вакуолізацією цитоплазми, ущільненням ядер та їх пікнозом, переважання гіперхромних та різко гіперхромних клітин Пуркіньє, значною дезорганізацією та порушенням закономірної локалізації нейронів у всіх шарах кори мозочка.

Ключові слова: кора мозочка; нейроцити; клітини Пуркіньє; термічна травма; мікроскопічні зміни.

\section{ВСТУП}

Термічна травма є стрес-чинником екзогенного походження [1, 3]. Безпосередньо, при ушкодженні шкірного покриву відбувається значна плазмовтрата, зростає токсичність сироватки крові, що у результаті призводить до синдрому ендогенної інтоксикації $[2,4]$. Згідно із дослідженнями, опікові токсини розносяться із кровотоком, викликають реактивні зміни в органах та системах організму [5-8]. Центральна нервова система виступає однією із провідних ланок відповіді на термічне ураження та сприймає надмірну больову імпульсацію. У результаті виникають морфологічні та фрункціональні зміни органів нервової системи, зокрема мозочка, який бере активну участь в процесах стрес-реактивності $[9,10]$. Відбувається структурна перебудова нейроцитів, їх часткова загибель та дегенерація волокон. Вивчення морфоорункціонального стану мозочка за умов різних станів і, зокрема термічної травми, залишається актуальним питанням у нейроморфології [11]. Зв'язок мозочка із багатьма відділами головного мозку і складна система обробки й аналізу інформації, яка поступає в його кору, роблять орган унікальним та багатосрункціональним.

Метою дослідження було встановити перебіг мікроскопічної реорганізації нейроцитів кори мозочка у динаміці за умов експериментальної термічної травми шкіри.

\section{МАТЕРІАЛИ I МЕТОДИ}

Дослідження проводили на 24 статевозрілих білих щурах-самцях, яких утримували у стандартних умовах віварію на збалансованому харчовому раціоні. Догляд за тваринами та всі маніпуляції проводили відповідно до Загальних етичних принципів експериментів на тваринах (Київ, 2001), які $€$
Conclusions. It is established that under the conditions of experimental thermal trauma there is a reorganization of neurocytes of the cerebellar cortex. On day 1 and 7 of the experiment there is a change in the shape of the perikaryons of neurons, hyperchromia of the nuclei, intracellular edema. In the long term there is an increase in destructivedegenerative changes, manifested by vacuolation of the cytoplasm, compaction of nuclei and their pyknosis, the predominance of hyperchromic and sharply hyperchromic Purkinje cells, significant disorganization and violation of the regular localization of neurons in all layers of the cerebellar cortex.

Key words: cerebral cortex; neurocytes; Purkinje cells; thermal trauma; microscopic changes.

узгодженими з Європейською конвенцією про захист експериментальних тварин (Страсбург, 1986).

Опікову травму наносили мідними пластинами, нагрітими у кип'яченій воді до температури 97-100 на епільовану поверхню шкіри спини та бічних поверхонь тіла тварин під тіопентал-натрієвим наркозом протягом 15 с. Тварин декапітували на 1, 7, 14 та 21 доби, що згідно із сучасною класифрікацією відповідає стадіям опікового шоку, ранньої та пізньої токсемії, септикотоксемії опікової хвороби. Забір матеріалу для мікроскопічного дослідження проводили згідно із загальноприйнятою методикою [14]. Шматочки мозочка фріксували в $96^{\circ}$ етиловому спирті та 10 \% нейтральному розчині фрормаліну, проводили дегідратацію у спиртах зростаючої концентрації, заливали у парафінові блоки. Для отримання напівтонких зрізів (1-2 мкм) шматочки тканини мозочка фріксували у 2,5 \% розчині глютаральдегіду, посторіксували 1 \% розчином тетраокису осмію на фоосфатному буфері. Подальшу обробку проводили згідно із загальноприйнятою методикою [14]. Напівтонкі зрізи, виготовлені на ультрамікротомі LKB-3, забарвлювали метиленовим синім. Гістологічні зрізи забарвлювали гематоксиліном та еозином, толуїдиновим синім за методом Ніссля та вивчали за допомогою світлового мікроскопа MICROmed SEO SCAN і фротодокументували за допомогою відеокамери Vision CCD Camera.

\section{РЕЗУЛЬТАТИ Й ОБГОВОРЕННЯ}

Гістологічні дослідження кори мозочка встановили, що на 1-шу добу після термічної травми більшість нейроцитів має збережену структуру, чітко диференційовані молекулярний, гангліонарний та зернистий шари кори мозочка. Зірчасті нейрони містять ядра, які мають не чіткі контури. Кошикоподібні нейроцити залягають у нижній третині молекулярного шару, мають полігональну фрорму. В деяких клітинах через 
1 добу експерименту спостерігається незначний перицелюлярний набряк та зміна форми. Клітини Пуркіньє гангліонарного шару розташовані однорядно, наявні нормохромні нейроцити, проте переважають гіпохромні із зменшенням розмірів грудочок субстанції Ніссля (рис. 1). Деякі нейрони мають незначні ознаки набряку та периферійного тигролізу. Гіпохромні клітини Пуркіньє змінюють фрорму із грушепобідної на округлу із внутрішньоклітинним набряком, відростки на деяких ділянках просвілені та потовщені. У цитоплазмі ядра гіпохромні іноді ексцентрично зміщені, в ядерцях збільшені та ущільнені. Клітини-зерна щільно розташовані у зернистому шарі, у деяких відзначається зміна фрорми перикаріонів. Ядро таких нейроцитів чітко контуроване і займає центральне положення.

Через 7 діб експерименту встановлено наростання морорологічних змін у шарах кори мозочка. У нейроцитах присутні ознаки альтерації. Зірчасті та молекулярні клітини мають видовжену фрорму, їх ядра мають збережену структуру. Деякі нейроцити молекулярного шару характеризуються перицелюлярним набряком. В гангліонарному шарі виявляється порушення розташування нейронів у один ряд. Гетерогенність нейроцитів цього шару проявляється наявністю поодиноких нормохромних із збільшеними зміненої фрорми ядрами. Переважають нейроцити різко гіпохромні із тотальним тигрозілом та відсутністю у нейроплазмі базофрільної речовини. Спостерігається незначна кількість гіперхромних клітин Пуркіньє, в яких за рахунок інтенсивного забарвлення цитоплазми, ядро і ядерце погано контуруються. Також визначаються різко гіперхромні нейрони, у яких нейроплазма і ядерні структури інтенсивно забарвлюється (рис. 2). У нейроцитах спостерігається перицелюлярний та внутрішньоклітинний набряк. Нейрони зернистого шару мають

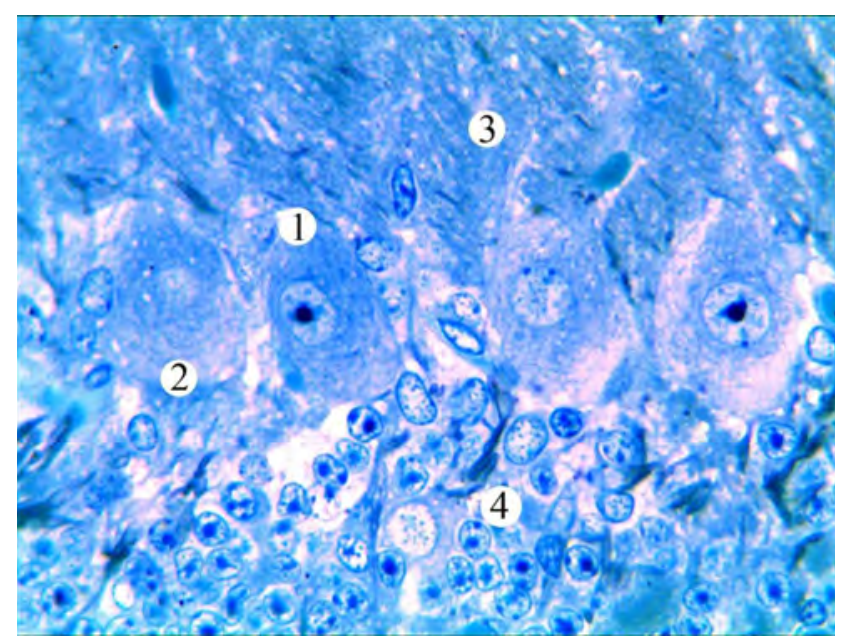

Рис. 1. Мікроскопічні зміни кори мозочка через 1 добу після експериментальної термічної травми: 1 - нормохромні та 2 - гіпохромні клітини Пуркіньє, 3 - молекулярний шар, 4 - зернистий шар кори мозочка. Забарвлення метиленовим синім. х400. дещо змінену форму, в яких також наявний інтра- та перицелюлярний набряк.

Мікроскопічні дослідження через 14 діб після експериментальної термічної травми встановили поліморфізм змін нейроцитів кори мозочка. У молекулярному шарі спостерігався перицелюлярний набряк зірчастих та кошикоподібних клітин. Їх перикаріони мали змінену фрорму, відростки дезоранізовані. Клітини Пуркіньє гангліонарного шару в стані тигролізу, який у більшості носить тотальний характер. У нейроплазмі таких гіпохромних та різко гіпохромних клітин містилося мало, невеликих грудочок хроматофрільної субстанції Ніссля або їх відсутність, що свідчить про виснаження нейроцитів. Також виявляється велика популяція гіперхромних та різко гіперхромних нейроцитів, що характеризувалися інтенсивно забарвленою нейроплазмою, перикаріони сплощеної форми, їх відростки витончені або частково потовщені. Зазначені зміни, які виникають у нейронах, підтверджуються науковими даними дослідників [12] і пов'язують 3 ендогенною інтоксикацією, що виникає після тяжкої опікової травми. Наявні ділянки у гангліонарному шарі кори мозочка, де клітини Пуркіньє розміщені щільно або значно розріджено. Зернистий шар втрачає свою структурованість нейроцитів, у більшості клітин-зерен наявні гіперхромні ядра, цитоплазма просвітлена, набрякла, вакуолізована (рис. 3). У цей термін досліду зберігається перицелюлярний набряк.

На 21 добу досліду виявлені значні деструктивні та дегенеративні зміни нейроцитів кори мозочка експериментальних тварин. Порушене пошарове розташування шарів. Спостерігається потовщення молекулярного шару, зірчасті та кошикоподібні клітини якого мають змінену форму із пікнотизованими, ущільненими ядрами, відзначається перицелюлярний набряк. Відзначається втрата однорядного розташування клітин Пуркіньє в гангліонарному

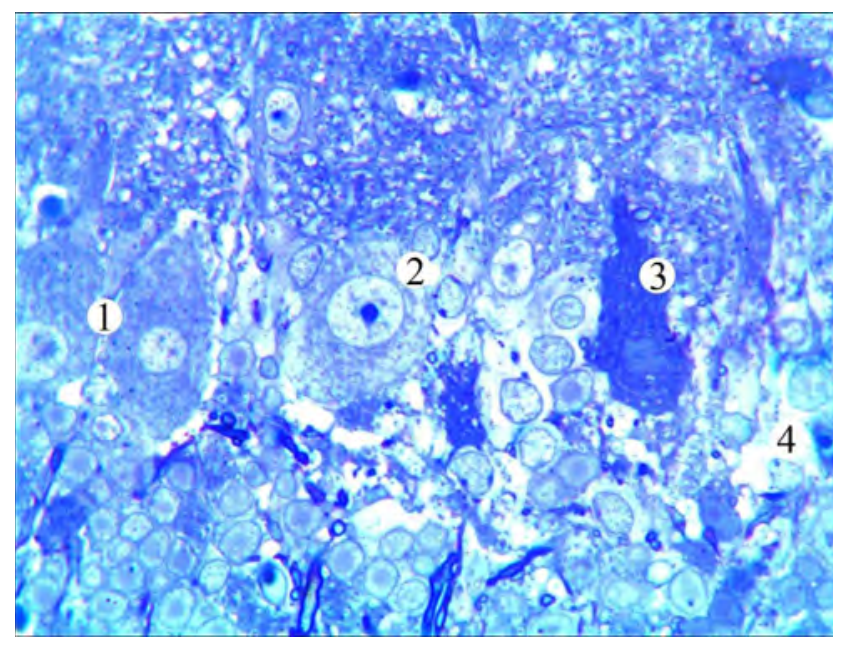

Рис. 2. Мікроскопічні зміни кори мозочка через 7 діб після експериментальної термічної травми: 1 - нормохромні, 2 - гіпохромні та 3 - гіперхромні клітини Пуркіньє, 4 - перицелюлярний набряк клітин-зерен зернистого шару кори мозочка. Забарвлення метиленовим синім. х400.
ISSN 2706-6282(print)

ISSN 2706-6290(online)
Вісник медичних і біологічних досліджень

Bulletin of Medical and Biological Research
$2(8), 2021$ 


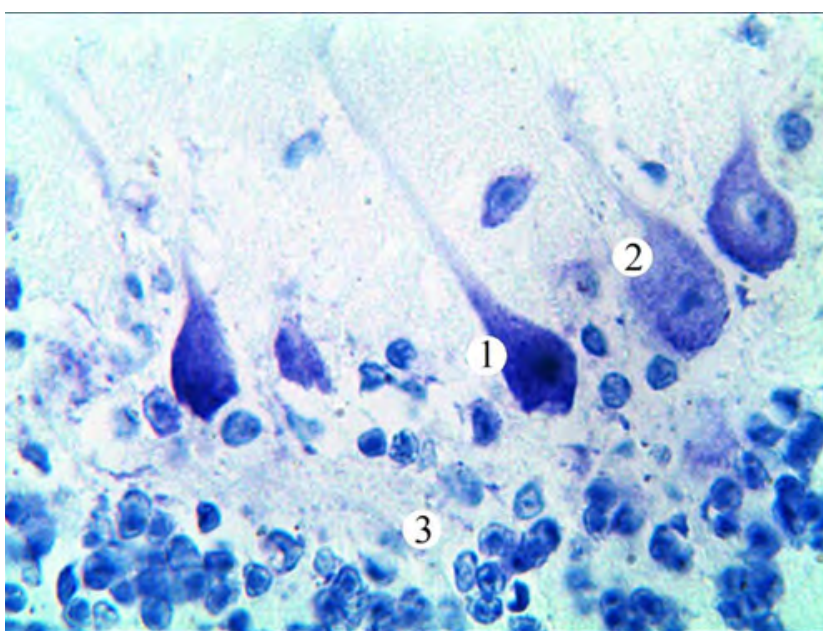

Рис. 3. Мікроскопічні зміни кори мозочка через 14 діб після експериментальної термічної травми: 1 - різко гіперхромні та 2 - гіпохромн клітини Пуркіньє, 3 - розрідження зернистого шару. Забарвлення толуїдиновим синім за методом Ніссля. х400.

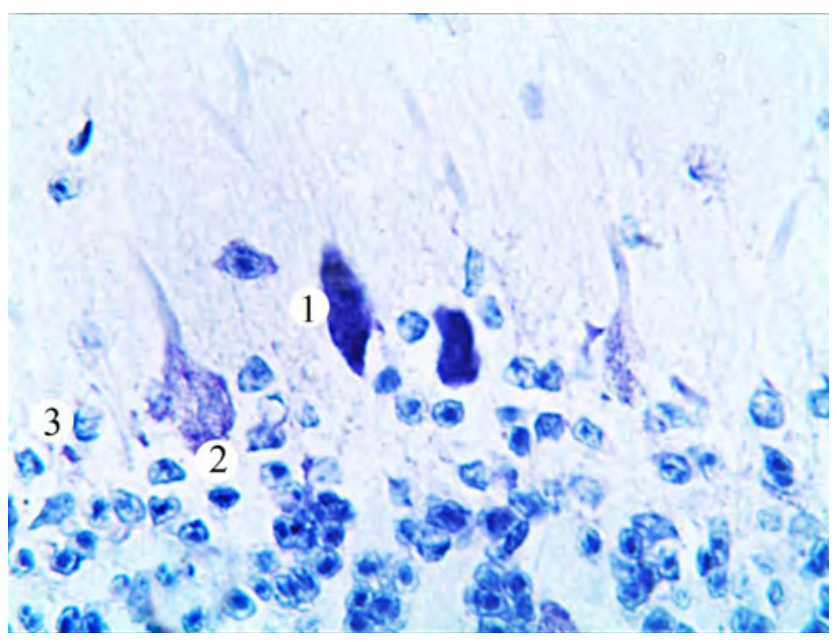

A шарі, виявляються пусті зони без нейроцитів, спостерігається їх часткова міграція у прилеглі молекулярний та зернистий шари. Нейрони характеризуються витонченими відростками, дезорганізовані. Більшість клітин Пуркіньє різко гіперхромна з інтенсивно забарвленою нейроплазмою, мають видовжену форму та округлі різко гіпохромні із тотальним тигролізом, повним зникненням грудочок хроматофрільної субстанції Ніссля (рис. 4, А). У зернистому шарі нейрони значно змінені, спостерігається їх перехід у гангліонарний шар, а також не щільне розташування та безклітинні ділянки. Клітини-зерна характеризуються деструктивно зміненою цитоплазмою та різко гіперхромними ядрами із значним набряком (рис. 4, Б). У віддалені терміни експерименту згідно із наших досліджень, встановлено, що клітини-зерна дезорганізовані, пікнотично змінені, $з$ інтра- та перицелюлярним набряком, що частково узгоджується з науковими даними [13].

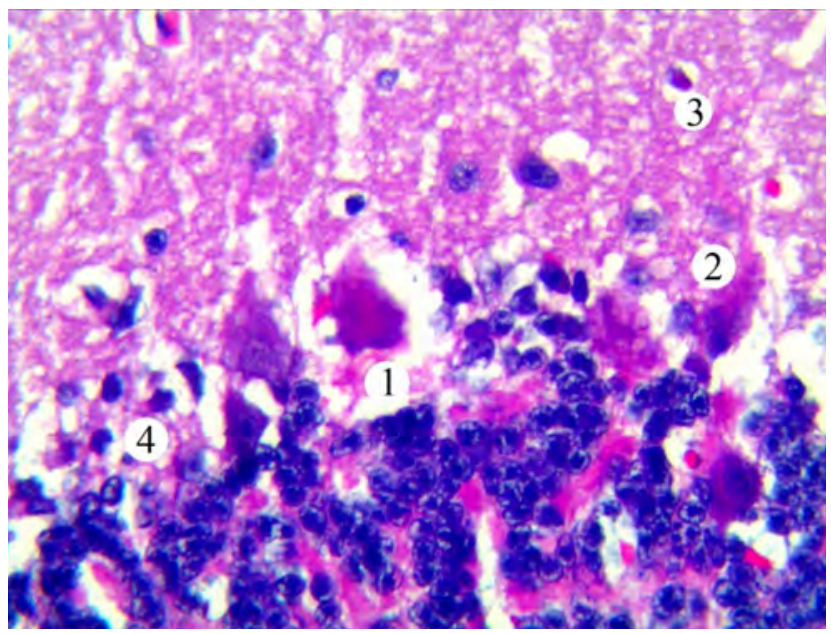

Б

Рис. 4. Мікроскопічні зміни кори мозочка через 21 добу після експериментальної термічної травми:

А. 1 - різко гіперхромні та 2 - гіпохромні клітини Пуркіньє, 3 - міграція клітин-зерен. Забарвлення толуїдиновим синім за методом Ніссля. х400; Б. 1 - гіперхромні й різко гіперхромні клітини Пуркіньє, 2 - перицелюлярний набряк нейроцитів 3 - молекулярного і 4 - зернистого шарів кори мозочка. Забарвлення гематоксиліном та еозином. х400.

\section{ВИСНОВКИ}

Встановлено, що у динаміці після експериментальної термічної травми мікроскопічні зміни в нейроцитах кори мозочка у ранні терміни носять пристосувально-компенсаторний характер та початкові деструктивні процеси на ороні ендогенної інтоксикації. Спостерігається поліморфізм клітин Пуркіньє, який полягає у переважанні гіпохромних, різко гіпохромних та гіперхромних нейроцитів. У пізні терміни порушення, які відбувалися у нейроцитах, носили незворотні деструктивні та дегенеративні зміни. Встановлено наростання інтра- та перицелюлярного набряку в усіх нейроцитах шарів кори мозочка. Підтвердженням незворотних порушень, які відбуваються в корі мозочка $€$ наявність вакуолізованих «кулястих» клітини Пуркіньє та клітин-«тіней».

\section{СПИСОК ЛІТЕРАТУРИ}

1. Ye H. Thermal injury of skin and subcutaneous tissues: A review of experimental approaches and numerical models / H. Ye, S. De // Burns. - 2017. - Vol. 43 (5). - P. 909-932. DOI: 10.1016/j.burns.2016.11.014.
2. Ковальчук О. І. Патогенез опікової хвороби: сучасні аспекти / О. І. Ковальчук // Наук. вісник НМУ ім. О.О. Богомольця. - 2013. - № 2 (41). - С. 64-69.

3. Pruitt B. A. An historical perspective on advance in 
burn care over the past 100 years / B. A. Pruitt, S. E. Wolf // Clin. Plast. Surg. 2009. - Vol. 36. - P. 527-545. DOI: 10.1016/j.cps.2009.05.007

4. Modelling early thermal injury using an ex vivo human skin model of contact burns / A. Liu, E. Ocotl, A. Karim [et al.] // Burns. - 2020. - Vol. 47 (3). - P. 611-620. DOI: 10.1016/j. burns.2020.08.011

5. Kramar S. B. Morphometric studies of the damaged skin area afterexperimental thermal trauma and during correction with cryo-lyophilized xenograft skin substrate / S. B. Kramar, K. S. Volkov, Z. M. Nebesna // Reports of Morphology. - 2018. - Vol. 24 (4). - P. 22-28. DOI: 10.31393/ morphology-journal-2018-24(4)-03.

6. Крамар С. Б. Мікроскопічні та гістохімічні зміни шкіри після експериментальної термічної травми при застосуванні кріоліофілізованого ксенодермального субстрату / С. Б. Крамар, К. С. Волоков, С. О. Литвинюк // Вісник морфології. - 2015. - № 1(1). - С. 6-9.

7. Submicroscopic changes of the respiratory alveolar macrophages at the late period after experimental thermal injury and in combined use of lyophilized xenograft substrate and surfactant / Z. M. Nebesna, K. S. Volkov, P. Ya. Bodnar [et al.] // Світ біології та медицини. - 2018. - Т. 2 (64). - С. 165-169.

8. Особливості ультраструктурної реорганізації передсердних кардіоміоцитів при експериментальній термічній травмі та за умов застосування ліофілізованих ксенодермотрансплантатів / І. Б. Гетманюк, 3. М. Небесна, П. Г. Лихацький, О. Я. Шутурма // Вісник наукових дослі-

\section{REFERENCES}

1. Ye H, De S. Thermal injury of skin and subcutaneous tissues: A review of experimental approaches and numerical models. Burns. 2017;43(5): 909-32. DOI: 10.1016/j. burns.2016.11.014.

2. Kovalchuk OI. [Athogenesis of burn diease: modern aspects]. Nauk. visnyk NMU im. O.O. Bohomoltsia. 2013;2(41): 64-9. Ukrainian.

3. Pruitt BA, Wolf SE. An historical perspective on advance in burn care over the past 100 years. Clin Plast Surg. 2009;36: 527-45. DOI: 10.1016/j.cps.2009.05.007

4. Liu A, Ocotl E, Karim A, Wolf JJ, Cox BL, Eliceiri KW, et al. Modelling early thermal injury using an ex vivo human skin model of contact burns. Burns. 2020;47(3): 611-20. DOI: 10.1016/j.burns.2020.08.011

5. Kramar SB, Volkov KS, Nebesna ZM. Morphometric studies of the damaged skin area afterexperimental thermal trauma and during correction with cryo-lyophilized xenograft skin substrate. Reports of Morphology. 2018;24(4): 22-8. DOI: 10.31393/morphology-journal-2018-24(4)-03.

6. Kramar SB, Volkov KS, Lytvynyuk SO. [Microscopic and histochemical changes of the skin after experimental thermal trauma and application of crioliofilized xenograftskin subst rate]. Visnyk morfolohii. 2015;1(1): 6-9. Ukrainian.

7. Nebesna ZM, Volkov KS, Bodnar PYa., Shuturma OYa., Kramar SB. Submicroscopic changes of the respiratory alveolar macrophages at the late period after experimental thermal injury and in combined use of lyophilized xenograft substrate and surfactant. World of Medicine and Biology. 2018;2(64): 165-9. джень. - 2019. - № 2(95). - С. 105-109. doi 10.11603/24158798.2019.2.10273.

9. Білаш С. М. Сучасні погляди на процеси реомоделювання структурних компонентів мозочка за умов дії комплексу хімічних речовин / С. М. Білаш, О. М. Проніна, Б. С. Кононов // Вісник проблем біології і медицини. - 2020. № 1(155). -20-25. doi: 10.29254/2077-4214-2020-1-155-20-25.

10. Coert J. H. Pathophysiology of nerve regeneration and nerve reconstruction in burned patients / J. H. Coert // Burns. - 2010. - Vol. 36 (5). - P. 593-598. DOI: 10.1016/j. burns.2009.10.007

11. Brain and cognitive impairments from burn injury in rats / M.-P. Halm, D. Poquin, P. Lestaevel, [et al.] // Burns. - 2006. - Vol. 32 (5). - P. 570-576. DOI: 10.1016/j. burns.2005.12.005.

12. Lytvynyuk S. O. Morphofunctional modifications of neurocytes of the rat hippocampal CA3 area after experimental thermal trauma / S. O. Lytvynyuk // Neurophysiology. - 2016. - Vol. 48. - P. 399-406.

13. Бекесевич А. М. Морфологічні особливості структури кори мозочка щура в нормі та за умов тривалого впливу опіоїду / А. М. Бекесевич // Запорож. мед. журн. - 2015. - № 3(90). - С. 82-85. doi:10.14739/23101210.2015.3.44505.

14. Горальський Л. П. Основи гістологічної техніки і морфоорункціональні методи досліджень у нормі та при патології / Л. П. Горальський, В. Т. Хомич, О.І.Кононський. - Житомир : Полісся, 2011. - 288 с.

8. Getmanyuk IB, Nebesna ZM, Lykhatskyi PG, Shuturma OYa. [Peculiarities of atrial cardiomyocytes' ultrastructural reorganization at experimental thermal injury and in conditions of application of lyophilized xenograft substrate]. Visnyk naukovykh doslidzhen. 2019;2(95): 105-9. doi 10.11603/2415-8798.2019.2.10273. Ukrainian.

9. Bilash SM, Pronina OM, Kononov BS. [Modern representations about processes of re-modeling of structural components of the cerebellum under conditions of action of the complex of chemicals]. Visnyk problem biolohii i medytsyny. 2020;1(155): 20-5. DOI: 10.29254/2077-42142020-1-155-20-25. Ukrainian.

10. Coert JH. Pathophysiology of nerve regeneration and nerve reconstruction in burned patients. Burns. 2010;36(5): 593-8. DOI: 10.1016/j.burns.2009.10.007

11. Halm M-P, Poquin D, Lestaevel P, Chancerelle Y, Graff C. Brain and cognitive impairments from burn injury in rats. Burns. 2006;32(5): 570-6. DOI: 10.1016/j.burns.2005.12.005.

12. Lytvynyuk SO. Morphofunctional modifications of neurocytes of the rat hippocampal CA3 area after experimental thermal trauma. Neurophysiology. 2016;48: 399-406.

13. Bekesevych AM. [Morphological features of the structure of the cerebellar cortex of rats in the norm and under prolonged exposure to the opioid]. Zaporozh med zhurn. 2015;3(90): 82-85. doi:10.14739/2310-1210.2015.3.44505. Ukrainian.

14. Horalskyi LP, Khomych VT, Kononskyi OI. Fundamentals of histological technique and morphofunctionalmethods of research in normal and pathology. [Основи гістологічної техніки і морфофрункціональні методи досліджень у нормі та при патологіï] Zhytomyr: Polissia; 2011. Ukrainian.

Отримано 06.03.21
ISSN 2706-6282(print)

ISSN 2706-6290(online)
Вісник медичних і біологічних досліджень

Bulletin of Medical and Biological Research
$2(8), 2021$ 